\title{
ORAL HEALTH OF OLDER ADULTS IN BRAZILIAN NURSING HOMES: CASE REPORT INVOLVING THE DEPARTMENT OF PUBLIC PROSECUTION
}

\author{
SAÚDE BUCAL DE IDOSOS EM INSTITUIÇÕES DE LONGA PERMANÊNCIA \\ NO BRASIL: RELATO DE CASO ENVOLVENDO A ATUAÇÃO DO MINISTÉRIO \\ PÚBLICO
}

\author{
Janaina Paiva CURI ${ }^{1}$; Mário Marques FERNANDES ${ }^{1,2}$; Mara Rosângeles de OLIVEIRA ${ }^{2}$; \\ Alexandre Raphael DEITOS ${ }^{3}$; Rogério Nogueira de OLIVEIRA $^{1}$; \\ Edgard MICHEL-CROSATO ${ }^{1}$ \\ 1. Community Dentistry Department, School of Dentistry, University of São Paulo - FOUSP; 2. Biomedical Service of the \\ Department of Public Prosecution of the State of Rio Grande do Sul; 3. Federal Criminal - Department of the Federal Police \\ /São Paulo, SP, Brasil
}

\begin{abstract}
The poor oral health of older adults, living in nursing homes (NH), affects their quality of life, requiring government protection in favor of the collectivity and to defend the social and individual rights of Brazilians. citizens This study reports a case investigated by the Department of Public Prosecution of Rio Grande do Sul/Brazil, which received complaints about the care provided to the residents of a nursing home, including oral care, which was unsatisfactory. A multidisciplinary team carried out visits to the institution and analysis, with professionals in the medical, nursing and dental fields. No mistreatment was confirmed, but dental healthcare revealed poor hygiene conditions that leaded to the confection of a Term of Conduct Adjustment (TCA), to be implemented in the inspected institution. Nevertheless, some of the elder residents still presented unsatisfactory oral health conditions, with some necessary action inside the institution to enhance the quality of life for this group.
\end{abstract}

KEYWORDS: Forensic dentistry. Department of Public Prosecution. Geriatrics.

\section{INTRODUCTION}

The number of older adults living in nursing homes $(\mathrm{NH})$ has been increasing in many countries (JUNGES et al., 2014). Therefore, the Department of Public Prosecution (DPP) has an important civil role, protecting collective interests, and guaranteeing and defending the social and individual rights of the Brazilian society (2) (3) (4).

Oral diseases associated or not with systemic diseases are common in NH. Loss of dexterity inherent to ageing directly hinders dental and denture hygiene, facilitating the development of many diseases in older adults (Chalhoub et al., 2014) since specific microorganisms are associated with aspiration pneumonia and vascular diseases (ADACHI et al., 2002) (EL-SOLH et al., 2003).

In addition to pneumonia, the rates of partial or complete edentulism, periodontal disease, and xerostomia in older adults is high (Leung et al., 2014), hence the need of reexamining the oral hygiene practices of this population (LEIBOVITZ et al., 2003).

Considering the need to inform and communicate scientific approach and good results achieved between the multidisciplinary health professional task force and the responsible for the ILP, together with the participation of Public Ministry in situations of collective an social interests, the objective of this case report is to discuss the oral health conditions of older adults living in NH in Rio Grande do Sul (RS), Brazil (BR), listing the reasons for poor oral health and proposing measures that improve the oral health of this population.

\section{CASE REPORT}

The present study was approved by the Research Ethics Committee of FOP-UNICAMP (OF.CEP/FOP $N^{\circ}$ 003/2011). It reports the action of the Department of Public Prosecution (DPP) of the State of Rio Grande do Sul against a NH. The DPP had received complaints of nighttime sedation and possible abuse from the residents' family members.

The first assessment was made by a multidisciplinary health team consisting of two physicians, one nurse, and one dentist. The study NH housed 26 older adults aged 60 to 101 years with various degrees of dependence, two of which 
were entirely dependent. All older adults were examined and their daily drug prescriptions reviewed.

The older adults' physical and mental health was compatible with their ages. The use of excessive sedation or signs of abuse were not confirmed. However, oral health assessment revealed poor hygiene, unsafe storage of tooth brushes and paste (Figure 1).

After the first assessment, the team proposed the implementation of an oral hygiene protocol integrated with the other services, to compose the NH's list of activities. A document called Term of Conduct Adjustment (TCA) forces the $\mathrm{NH}$ to implement and follow the protocol and to keep specific individual dental records.

The protocol proposes included the following procedures: A. Tooth brushing twice a day and cleaning the tongue once a day, by the caregivers or older adult himself; B. Extraoral denture cleaning at least once a day; C. Denture removal after each meal to rinse in tap water and remove debris; D. Denture removal at night to allow tissue relief and aeration. The denture should be placed in cup with water; E. Edentulous adult's mouth and tongue cleaning with moist gauze; F. Weekly complementary denture cleaning by immersing denture overnight in a $0.02 \%$ sodium hypochlorite solution in a lidded container. The denture must be rinsed before use and the hypochlorite solution discarded; G. Individual tooth brush cleaning, drying, and storage in a safe place.

After the TCA was signed, the $\mathrm{NH}$ was inspected by technical assistants (dentists) two more times at roughly 45-day intervals. The new assessments again found poor oral hygiene evidenced by food debris on the dentures, partly disagreeing with the proposed protocol. Some protocol items were re-explained to the caregivers. But improvements were also noticed, such as better storage of dentures, and tooth brushes and paste (Figure 2, A and B), and individual daily records of oral events (Figure 2, C).

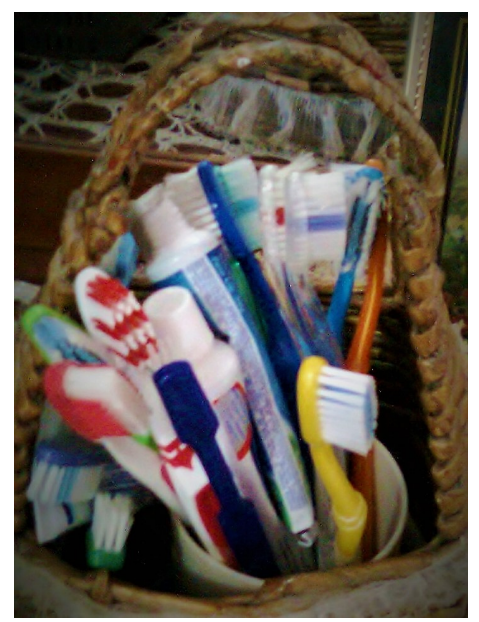

Figure 1. Unsafe storage of tooth brushes and paste in a single container

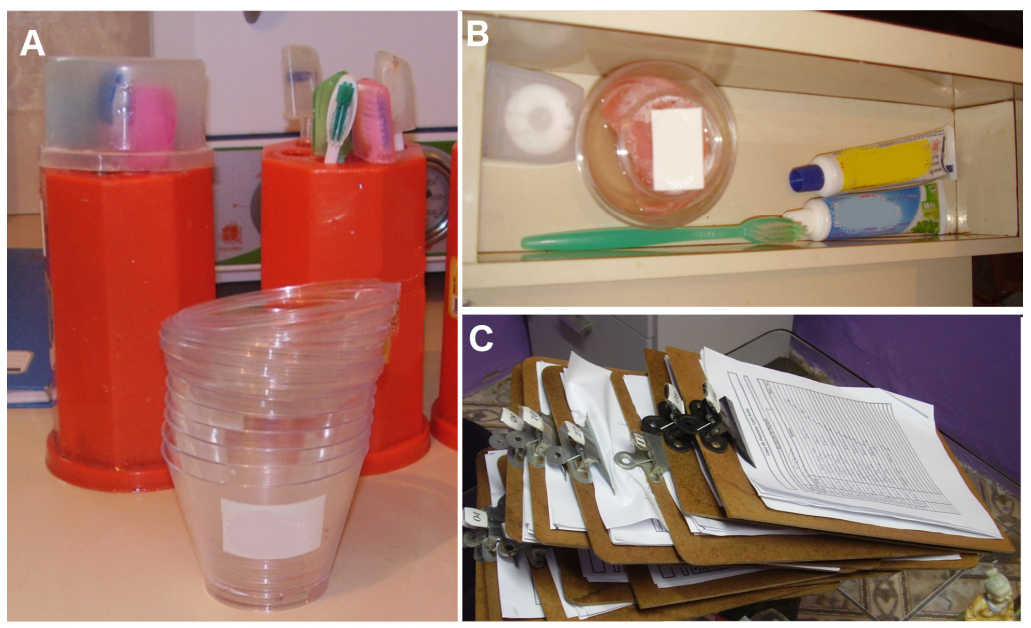

Figure 2. Tooth brushes and paste stored correctly (A); Denture stored in a lidded container (B); Individual daily records of dental events (C). 


\section{DISCUSSION}

TCA implementation, legally supported by the DPP, was a practical and functional option for the NH, considering its socioeconomic status. The $\mathrm{NH}$ has depended for years on the monthly payments made by the older adults' family members and on the voluntary help of drugstores, which donated pharmaceuticals. Issues, such as, abandonment, loss of close relatives, family conflicts and the necessity of constant health supervision are frequent motives that lead older citizens to seek for shelters. (DE LARGA; DE ADAPTACIÓN, 2008).

The Brazilian Constitution of 1988 (BRASIL, 1988 ) which aims to protect and ensure service quality and to control the sector responsible for older adult health, affirms that not only the family, but also the society and the State, are responsible for sheltering their older adults and for guaranteeing the dignity and wellbeing of people older than 60 years (CAMARANO; KANSO, 2010; DE CARVALHO, 2014). In other countries, such as the United States, government reports show the inefficiency of $\mathrm{NH}$ rules in promoting better health care in many nursing homes, resulting in lawsuits (LOLLI et al.; TROYER; THOMPSON, 2004; DE CASTRO PINTO; VON SIMSON, 2012).

Another legal instrument, Board Resolution (RDC) $\mathrm{n}^{\mathrm{o}} 283 / 05$ of the National Sanitary Surveillance Agency, responsible for regulating NH in Brazil, requires $\mathrm{NH}$ to establish a minimum service standard for older adults, such as employment contracts and resident care, and to have enough employees to meet the degree of dependency of its residents (ANVISA, 2007). The number of employees of the study $\mathrm{NH}$ was inadequate: only two for 26 older adults with various degrees of dependence. At least two more employees should be hired for proper care.

Malnutrition, abuse, and incorrect pharmaceutical use are factors strongly associated with progressive health deterioration (Poisson et al., 2014), which increases dependence in activities of daily living and care cost (SINGH et al., 2014). Although the presence of these factors was not confirmed, the oral condition of the residents was unsatisfactory, evidenced by poor denture maintenance and clinical condition of the remaining teeth. These findings may have a negative impact on resident health because of the possible association between poor oral hygiene in institutionalized older adults and the occurrence of anaerobic aspiration pneumonia (EL-SOLH et al., 2003).
It is a fact that older adults need assistance in all aspects of daily living and it could not be different with respect to oral hygiene, making the presence of properly trained professionals critical (MEHL et al., 2014; DOS SANTOS TAVARES et al., 2017). Even though many of the cases of abuse are difficult to be noticed by general dental surgeons, (SILVA et al., 2017), the multidisciplinary team has recorded, after clinical and physical exams, insufficient practices of basic oral care, despite the fact that the caregivers considered that the proper care was being offered with adequate regularity.

Many dental problems present in older adults are complications caused by the accumulation of pathological processes that occur throughout life. The main oral changes found in the Brazilian population are dental caries, periodontal diseases, abrasion, various lesions, oral cancer, and tooth loss (Roncalli, 2011). These changes may vary according to the institutionalization status of these individuals (CARNEIRO et al., 2005).

In face of the findings, the study $\mathrm{NH}$ was forced by the DPP to implement the TCA, distributing functions and responsibilities to their staff, which included: advising the residents about oral and denture cleaning, performing mechanical cleaning to remove plaque followed by chemical cleaning using specific products to remove and kill microorganisms (Nishi et al., 2014); storing tooth brushes individually; recording of all dental events in specific forms.

Although the activities proposed by TCA can be relatively easily performed by the employees, subsequent inspections found partial noncompliance with the protocol. One explanation is that improved oral health in nursing homes requires changing the behavior of residents and especially, of caregivers, in addition to implementing educational and assistance strategies that promote a multidisciplinary intervention in the health-disease process of vulnerable individuals (ROCHA; MIRANDA, 2013), which is a challenge for NH.

$\mathrm{O}$ presente relato traz uma solução viável em relação à adequação das ações e cuidados com a saúde de idosos que vivem em instituições, por meio da implementação do TAC, resultando não somente na recuperação de saúde bucal dos indivíduos residentes, mas também gerando um impacto positivo na qualidade de vida dos mesmos. The present report, provides a valuable solution, concerning the adjustment of actions and oral care to older residents of institutions, by using the TCA to both educate and enhance services with the aim on better health. Performing a rigorous oral hygiene 
protocol could not only reduce the colonization of the oral cavity by potentially pathogenic organisms but also provide caregivers with technical data for the gradual and continuous improvement of their skills, so that they may provide the residents with more comprehensive care.

\section{CONCLUSION}

Using an oral hygiene protocol, the DPP intervention improved the quality of care provided to the residents of the study nursing home. However, the oral hygiene of the residents remained unsatisfactory. Improving the quality of life of this group requires ongoing educational activities, including actions that promote oral health and prevent problems; training caregivers so that they can carry out the proposed protocol; and adjustment of the number of health-related human resources in compliance with the legislation.

RESUMO: A precariedade das condições de saúde bucal de idosos residentes em instituições de longa permanência afeta a qualidade de vida deste grupo, que necessita da tutela do poder público em favor de interesses coletivos com o intuito de garantir e defender os direitos sociais e individuais dos brasileiros. Este trabalho tem o objetivo de relatar um caso investigado pelo Ministério Público do Rio Grande do Sul/Brasil, partindo de denúncias a respeito da precariedade dos cuidados com a higiene oral em idosos institucionalizados. As visitas e avaliações foram feitas por uma equipe de saúde multidisciplinar composta por médicas, uma enfermeira e uma cirurgiã-dentista. Não foram confirmados sinais de maus-tratos. Contudo, a avaliação da saúde bucal revelou condições insatisfatórias de higiene, resultando na elaboração de um Termo de Ajustamento de Condutas (TAC), pela equipe de saúde, o qual foi implementado na ILP. O TAC propiciou melhorias envolvendo o cuidado aos residentes da instituição inspecionada. Entretanto, os idosos ainda apresentam condições de higiene bucal insatisfatórias, sendo necessárias alguns ações dentro da instituição para que haja uma melhora da qualidade de vida deste grupo.

PALAVRAS-CHAVE: Odontologia Legal. Ministério Público. Gerontologia.

\section{REFERENCES}

ADACHI, M. et al. Effect of professional oral health care on the elderly living in nursing homes. Oral Surg Oral Med Oral Pathol Oral Radiol Endod, v. 94, n. 2, p. 191-5, Aug 2002. ISSN 1079-2104. Available at: < http://www.ncbi.nlm.nih.gov/pubmed/12221387>. Access on 12 Oct 2016.

https://doi.org/10.1067/moe.2002.123493

ANVISA, A. N. D. V. S. RDC no 94 de 31 de dezembro de 2007. Modifica a RDC no 283, set 2005. Regulamento Técnico que define as normas de funcionamento para as instituições de longa permanência para idosos. 2007. https://doi.org/10.11606/d.22.2012.tde-05112012-144202

BRASIL. Constituição Federal. CAP II, art 230: 133 p. 1988

CAMARANO, A. A.; KANSO, S. As instituições de longa permanência para idosos no Brasil. Revista brasileira de estudos de população, v. 27, n. 1, p. 232-235, 2010. ISSN 0102-3098.

https://doi.org/10.1590/s0102-30982010000100014

CARNEIRO, R. M. et al. [Oral health of institutionalized elderly in the eastern zone of São Paulo, Brazil, 1999]. Cad Saude Publica, v. 21, n. 6, p. 1709-16, 2005 Nov-Dec 2005. ISSN 0102-311X. Available at: < http://www.ncbi.nlm.nih.gov/pubmed/16410855 >. Access on 05 Oct 2016. https://doi.org/10.1590/s0102$311 \times 2005000400033$

CHALHOUB, E. et al. Effectiveness of an alcohol-free essential oil-containing mouthwash in institutionalised elders receiving long-term care: a feasibility study. Gerodontology, Mar 2014. ISSN 1741-2358. Available at: < http://www.ncbi.nlm.nih.gov/pubmed/24593317 >. Access on 05 Oct 2016. https://doi.org/10.1111/ger.12119 
DE CARVALHO, V. L. Perfil das instituições de longa permanência para idosos situadas em uma capital do Nordeste. 2014. https://doi.org/10.1590/1414-462x201400020012

DE CASTRO PINTO, S. P. L.; VON SIMSON, O. R. D. M. Instituições de longa permanência para idosos no Brasil: sumário da legislação. Revista Brasileira de Geriatria e Gerontologia, v. 15, n. 1, p. 169-174, 2012. ISSN 1809-9823. https://doi.org/10.1590/s1809-98232012000100018

DE LARGA, A. E. I.; DE ADAPTACIÓN, P. Y. P. Motivações para o ingresso dos idosos em instituições de longa permanência e processos adaptativos: um estudo de caso. 2008. https://doi.org/10.1590/s010407072008000200006

DOS SANTOS TAVARES, D. M. et al. Access determinants and use of health services among the elderly. Bioscience Journal, v. 33, n. 4, 2017. ISSN 1981-3163.

EL-SOLH, A. A. et al. Microbiology of severe aspiration pneumonia in institutionalized elderly. Am J Respir Crit Care Med, v. 167, n. 12, p. 1650-4, Jun 2003. ISSN 1073-449X. Available at: < http://www.ncbi.nlm.nih.gov/pubmed/12689848 >. Access on 08 Oct 2016. https://doi.org/10.1164/rccm.200212-1543oc

JUNGES, R. et al. Caregivers' attitudes regarding oral health in a long-term care institution in Brazil. Gerodontology, v. 31, n. 3, p. 178-83, Sep 2014. ISSN 1741-2358. Available at: < http://www.ncbi.nlm.nih.gov/pubmed/23134197 >. Access on 12 Oct 2016. https://doi.org/10.1111/ger.12019

LEIBOVITZ, A. et al. Saliva secretion and oral flora in prolonged nasogastric tube-fed elderly patients. Isr Med Assoc J, v. 5, n. 5, p. 329-32, May 2003. ISSN 1565-1088. Available at: < http://www.ncbi.nlm.nih.gov/pubmed/12811948 >. Access on 12 Oct 2016.

LEUNG, D. Y. P.; LEUNG, A. Y. M.; CHI, I. Factors associated with chewing problems and oral dryness among older Chinese people in Hong Kong. Gerodontology, v. 32, n. 1, p. 01-10, 2014. https://doi.org/10.1111/ger.12116

LOLLI, L. F. et al. Atos ocultos de violência praticados contra idosos institucionalizados em associação ao perfil de cuidadores. Bioscience Journal, v. 29, n. 1, ISSN 1981-3163.

MEHL, A. E. et al. Oral healthcare education of future nursing personnel and auxiliary nurses.

Gerodontology, Sep 2014. ISSN 1741-2358. Available at: < http://www.ncbi.nlm.nih.gov/pubmed/25209113 $>$.

NISHI, Y. et al. Survival of microorganisms on complete dentures following ultrasonic cleaning combined with immersion in peroxide-based cleanser solution. Gerodontology, v. 31, n. 3, p. 202-9, Sep 2014. ISSN 1741-2358. Available at: < http://www.ncbi.nlm.nih.gov/pubmed/23215771 >. https://doi.org/10.1111/ger.12027

POISSON, P. et al. Relationships between oral health, dysphagia and undernutrition in hospitalised elderly patients. Gerodontology, Mar 2014. ISSN 1741-2358. Available at: < http://www.ncbi.nlm.nih.gov/pubmed/24612262 >. https://doi.org/10.1111/ger.12123

ROCHA, D. A.; MIRANDA, A. F. Atendimento odontológico domiciliar aos idosos: uma necessidade na prática multidisciplinar em saúde: revisão da literatura. Rev. Bras. Geriatr. Gerontol, v. 16, n. 1, p. 181-189, 2013. https://doi.org/10.1590/s1809-98232013000100018

RONCALLI, A. G. Projeto SB Brasil 2010: pesquisa nacional de saúde bucal revela importante redução da cárie dentária no país. Cadernos de Saúde Pública, v. 27, n. 1, p. 4-5, 2011. https://doi.org/10.1590/s0102$311 \times 2011000100001$ 
SILVA, L. O. et al. Identification and management of elder physical abuse in the routine of dentistry-a systematic review. Gerodontology, v. 34, n. 1, p. 3-12, 2017. ISSN 0734-0664.

https://doi.org/10.1111/ger.12252

SINGH, D. K. et al. Correlation between nutritional status and comprehensive physical performance measures among older adults with undernourishment in residential institutions. Clin Interv Aging, v. 9, p. 1415-23, 2014. ISSN 1178-1998. Available at: < http://www.ncbi.nlm.nih.gov/pubmed/25187701 >.

https://doi.org/10.2147/cia.s64997

TROYER, J. L.; THOMPSON, H. G. The impact of litigation on nursing home quality. J Health Polit Policy Law, v. 29, n. 1, p. 11-42, Feb 2004. ISSN 0361-6878. Available at: <

http://www.ncbi.nlm.nih.gov/pubmed/15027836 >. https://doi.org/10.1215/03616878-29-1-11 